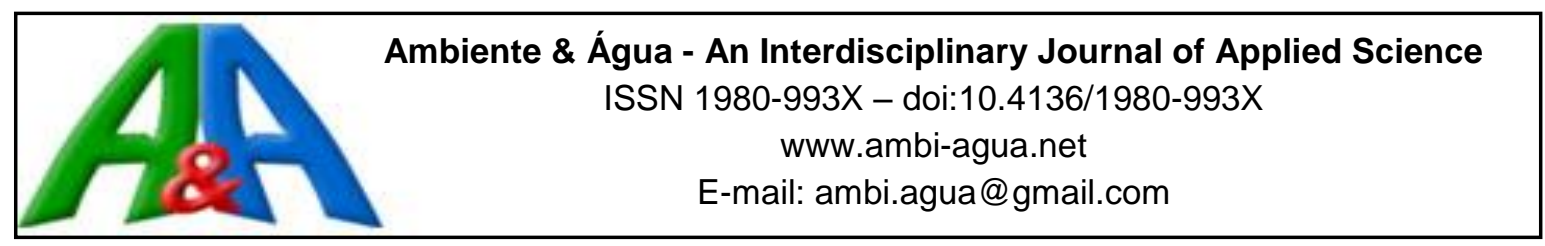

\title{
Critical evaluation of the factors affecting Escherichia coli environmental decay for outfall plume models
}

\author{
ARTICLES doi:10.4136/ambi-agua.2106 \\ Received: 03 Mar. 2017; Accepted: 17 May 2018 \\ Marcos Tavares Carneiro'; Myriam Bandeira Vianna Cortes²; \\ Julio Cesar Wasserman ${ }^{3 *}$ \\ ${ }^{1}$ Universidade Federal Fluminense (UFF), Niterói, RJ, Brasil \\ Programa de pós-graduação em Sistema de Gestão Sustentáveis (PPSIG) \\ E-mail: marcostavares19@gmail.com \\ ${ }^{2}$ Universidade Federal Fluminense (UFF), Niterói, RJ, Brasil \\ Departamento de Microbiologia e Parasitologia (MIP). E-mail: mbviann@gmail.com \\ ${ }^{3}$ Universidade Federal Fluminense (UFF), Niterói, RJ, Brasil \\ Departamento de Análise Geoambiental (GAG). E-mail: geowass@ vm.uff.br \\ *Corresponding author
}

\begin{abstract}
The Escherichia coli $T_{90}$ parameter is widely employed in outfall plume hydrodynamic models. Although there is a great deal of academic literature estimating $T_{90}$, no standard methodology has been validated so far. Estimation of die-off rates should consider many other biological, chemical and physical processes. Over the last three decades, while a great deal of new knowledge about microbial biology and ecology has become available, it has not been fully incorporated into the overall research. Consequently, hydrodynamic models of sewage plumes lack consistency with environmental dynamics and frequently do not fully reproduce processes. This article scrutinized the relevant works that could improve $T_{90}$ assessment using the most robust and realistic approaches. The most important related literature since the 1990s was considered, together with earlier relevant works. The research focused on techniques and methodologies, especially their ecologic and cellular biology aspects. A brief discussion of the methods applied to evaluate the $T_{90}$ of bacteria examined aspects like representativeness of incubation, incubation scale, measurement procedures and models' representations of bacterial decay. The factors affecting population decay, such as solar radiation, salinity and interaction with solids, were considered in the light of the very large literature registry. Finally, biological aspects affecting decay, like predation and genetic resistance, were also analyzed. The resulting updated understanding of $T_{90}$ may contribute to better managerial procedures that could improve water quality in freshwater and coastal systems, and consequently improve human health outcomes.
\end{abstract}

Keywords: bacteria, environmental decay, water quality.

\section{Avaliação crítica dos fatores que influenciam o decaimento de Escherichia coli para modelagem de plumas de emissários submarinos}

\section{RESUMO}

O parâmetro $T_{90}$ de Escherichia coli é muito empregado na modelagem hidrodinâmica de plumas de emissários submarinos. Apesar da extensa literatura disponível que aplica $T_{90} \mathrm{em}$ 
modelos hidrodinâmicos, não existe uma padronização metodológica para sua avaliação que seja validada até hoje. Além das taxas de decaimento, muitos outros processos biológicos, químicos e físicos deveriam ser considerados nas modelagens hidrodinâmicas. Nas últimas três décadas, embora um extenso conhecimento sobre biologia e ecologia microbiana tenha sido desenvolvido, pouco deste conhecimento foi incorporado às aplicações. Consequentemente, os modelos de plumas de esgotos não lograram reproduzir de maneira fiel os processos ambientais. No presente artigo, os trabalhos relevantes que poderiam melhorar a determinação do $T_{90}$, sob abordagens mais robustas e realistas foram revisados. A literatura mais relevante desde os anos 1990 foi considerada, juntamente com alguns trabalhos relevantes mais antigos. A pesquisa focou em técnicas e metodologias de avaliação de aspectos ecológicos e de biologia celular. Uma breve discussão dos métodos aplicados à avaliação do $T_{90}$ examinou aspectos como a representatividade das incubações, escala dos experimentos de incubação e procedimentos de medição, com ênfase em modelos de decaimento bacteriano. Os fatores que afetam o decaimento bacteriano como radiação solar, salinidade e interação com sólidos foram considerados à luz do extenso registro da literatura. Finalmente, aspectos biológicos que afetam o decaimento como predação e resistência genética foram analisados. O entendimento atualizado resultante da pesquisa com $T_{90}$ pode contribuir para o desenvolvimento de procedimentos de gestão que podem melhorar a qualidade da água em sistemas costeiros e continentais, dando soluções para problemas de saúde em populações humanas.

Palavras-chave: bactéria, decaimento ambiental, Escherichia coli, qualidade de água.

\section{INTRODUCTION}

One of the most widely used and cost-effective destinations for the disposal of large amounts of domestic sewage is marine outfalls, especially in coastal areas (Yang et al. 2000). Despite its popularity, this method constitutes a population health risk because bacteria can remain alive for a long time (Alkan, 1999; van Elsas et al., 2011). In fact, previous studies have shown that coliforms from domestic sewage, including the pathogenic Escherichia coli strains, can survive for long periods of time (Omar 2010) as Viable But Not Cultivable (VBNC) organisms, retaining their enteropathogenicity (Lothigius et al., 2010, Pommepuy, et al. 1996a; van Elsas et al., 2011). The pathogenic E. coli, however, is not the only danger present in domestic sewage. In fact, in the present study, we regarded it principally as an indicator of overall pollution risk (de Brauwere et al. 2014b). The management of that risk starts long before the outfall step, because the construction of a waste management technique requires hydrodynamic modeling that can assess the environmental impacts on the surrounding ecosystems (Fernández, 2011, Yang et al., 2000).

Finite element, finite differences, and other transport numeric models are adequate tools that enable the forecasting of results of a process before it happens (Feitosa et al., 2013a; Fernández, 2011; Rodrigues et al., 2011). On the other hand, the model must be fed with consistent local parameters (Ozcan, 2002) and rates (Chan et al., 2015) that yield realistic estimations. In outfall modeling, one of the important parameters of the environmental conditions is the time required for $90 \%$ of the E. coli to die-off ( $E$. coli $\mathrm{T}_{90}$ ), and several researchers throughout the world have come up with values for this parameter (Table 1) under various conditions (Chan et al., 2015; Feitosa et al., 2013a; Jozić et al., 2014; Rozen, 2001; Yang et al., 2000). 
Table 1. E. coli die-off values $\left(\mathrm{T}_{90}\right)$ obtained from the literature.

\begin{tabular}{|c|c|c|c|}
\hline Location & $\mathrm{T}_{90}$ ranges & Specific conditions & Authors \\
\hline $\begin{array}{l}\text { Laboratory, with } \\
\text { samples collected from } \\
\text { Taiwan, China }\end{array}$ & $1.67-3.17$ hours & $\begin{array}{l}\text { In the presence of predators, sea } \\
\text { water during daytime and night } \\
\text { respectively }\end{array}$ & (Yang et al., 2000) \\
\hline Various & $1.9-46.4$ hours & $\begin{array}{l}\text { Various locations, reviewing the } \\
\text { data of various authors }\end{array}$ & (Feitosa et al., 2013a) \\
\hline Laboratory & $0.31-190$ hours & $\begin{array}{l}\text { Experiments with two } E \text {. coli } \\
\text { ATCC strains under solar } \\
\text { radiation or in the dark }\end{array}$ & (Jozić et al., 2014) \\
\hline Hong Kong & $10.8-42.3$ hours & Daylight in situ experiments & (Chan et al. 2015) \\
\hline New Zealand & $\begin{array}{l}100-135 \text { hours } \\
\text { dark } \\
3.3-20.3 \text { hours } \\
\text { under sunlight }\end{array}$ & $\begin{array}{l}\text { outdoor experimental open-top } \\
\text { chambers light and dark } \\
\text { conditions }\end{array}$ & (Sinton et al., 2002) \\
\hline
\end{tabular}

Research on E. coli $\mathrm{T}_{90}$ has found values ranging from 2 hours to many days, under both light and dark conditions (Chan et al., 2015; Craig et al., 2004; Jozić et al., 2014; Lothigius et al., 2010; Zhang et al. 2015). The large variation is the result of the varying conditions under which these studies were carried out (Alkan et al., 1995; Berney et al., 2006; Craig et al., 2002; 2004; Lothigius et al., 2010; Moriñigo et al., 1990; Rozen, 2001). Thus, as already noted by Alkan et al. (1995) in the 1990s, it is still not fully understood even now how the varying factors act on $E$ coli $T_{90}$ or how intensely they act.

This study reviewed the current knowledge about the factors affecting the $T_{90}$ of $E$. coli, summarizing the ways in which studies have been carried out, and analyzing their methodological design in order to suggest new paths for improvements. Available literature about marine E. coli from the last 30 years were surveyed, and the most significant studies beyond this period as well. A particular focus was addressing the methods and parameters employed in these studies, the resulting decay models, and the obtained data. Other factors that could influence $T_{90}$ were also discussed.

\section{ADEQUACY OF E. COLI PARAMETERS FOR OUTFALL-PLUME MODELING}

The study of the E. coli $T_{90}$ of outfall plumes started with the premise that this organism is a reliable indicator of the presence of domestic sewage (Craig et al., 2004), and has been used in several contaminant models, becoming almost a standard. Recently, more attention has been focused on $E$. coli $T_{90}$, as a result of increasing water pollution, antibiotic resistance, and enterophatogenicity in the environment (Araujo et al., 2016; Carneiro et al., 2015; FernándezDelgado and Suárez 2009; Griffith et al., 2016; Nataro and Kaper, 1998; Omar, 2010; Pommepuy et al., 1996b; USEPA, 2009). Notwithstanding this, it is important to highlight that although there is a relationship between $E$. coli bacterial counts and sewage, no relationship has currently been established between $E$. coli counts and pathogenic bacteria (Carneiro et al., 2015; Omar, 2010). Thus, whether to consider E. coli a sewage pollution bioindicator (a Fecal Indicator Bacteria (FIB)) or simply a pathogen to be monitored has not yet been determined. Before that determination can be made, its population dynamics in the environment need to be better understood. For this purpose, the academic community should increase research on $E$. coli $T_{90}$, trying to balance the best tools for scientific study with practical management of environmental systems. This important discussion must be pursued (Bucci et al., 2011; Craig

\section{IPABH}

Rev. Ambient. Água vol. 13 n. 4, e2106 - Taubaté 2018 
et al. 2004; Nataro and Kaper 1998; Omar, 2010; Pommepuy et al., 1996b; van Elsas et al., 2011).

Although E. coli have been broadly used in modeling, other microorganisms and molecular markers have been studied as alternative indicators. In most studies, Enterococcus sp. seems to present longer $T_{90} \mathrm{~s}$, but requires less accumulated radiation to decay. Coliform bacteria have shown lower $T_{90}$ than coliphages, (e.g., F-DNA phages, Bacteroides fragilis phages, F-RNA phages, Clostridium perfringens) and markers (e.g., Enterococci 23S rRNA [ENT-23] and Escherichia coli [EC-uidA]), in several types of matrices (Alkan et al., 1995; Brooks et al., 2015; Davies-Colley et al., 1994; Sinton et al., 1999; Zhang et al., 2015). On the other hand, Rippy et al. (2013) encountered larger Enterococcus decay rates (lower $T_{90}$ ) than E. coli in Huntington Beach, California, U.S.A. (using the enzymatic method). This apparent contradiction could be the result of the different methodological approaches to study the application of culture or enzymatic method to VBNC (Viable But Not Cultivable) bacteria, as will be further discussed in this article.

\section{METHODS FOR EVALUATING E. COLI POPULATION DECAY}

\subsection{Decay factors}

From the literature, one can observe two principal factors engendering bacterial population decay in the environment. The first is composed of physical processes that separate cells from one another: these are principally currents and tides, dilution, adsorption, sedimentation and resuspension (Alkan, 1999; de Brauwere et al., 2014a; Craig et al. 2004). Another factor affecting decay is biological. Biological decay can be led, modulated and minimized by solar radiation, turbidity (radiation attenuation), salinity, predation, temperature, $\mathrm{pH}$, competition, growth under different nutrient conditions, and growth under the release of nutrients from dead cells (Alkan et al., 1995; Beardsley et al., 2003; Bucci et al., 2011; Carrillo et al., 1985; Chan et al., 2015; Davies-Colley et al., 1994, Jozić et al., 2014, Troussellier et al., 1998; van Elsas et al., 2011; Yang et al., 2000). Jozić et al. (2014) adds to that list variations at the gene level, which can improve bacterial resistance. The results of both physical and biological processes might explain the so-called biphasic decay. As stated by Bucci et al. (2011), biphasic decay is characterized by an early period with a higher apparent first-order constant decay rate, followed by a later period with a lower constant rate. Obviously, in the environment these two large decay phases act together, making decay studies even more complex and hard to simulate with first-order decay models (Figure 1).

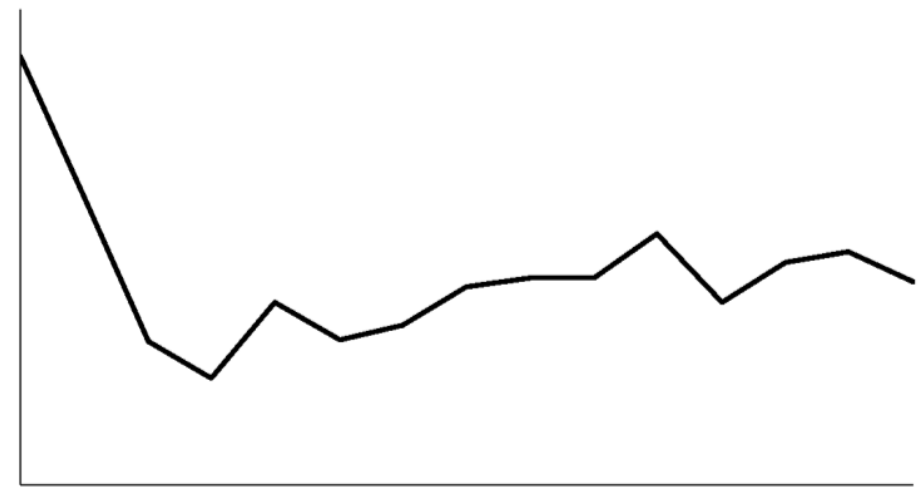

Figure 1. An example of the biphasic decay of E. coli. Inoculated in phosphate buffer solution (PBS). Escherichia coli K-12 MG1655 strain MV1973, which is a streptomycin resistant (adapted from Bucci et al., 2011). 


\subsection{Increasing Methodological robustness on assays}

Biological, molecular and environmental factors act synergistically to alter the E. coli $T_{90}$ (van Elsas et al., 2011), and this general frame cannot be assessed with simple experimental arrangements. Hence the $T_{90}$ studies in seawater depend to a large extent upon the methodologies adopted (Rozen, 2001). An example of this dependency was given by Rhodes (1988), who studied E. coli survival in estuarine conditions, observing a less than one-log population decrease. In this case, inoculum with filtered water was maintained for 16 days in in situ diffusion chambers, while other in situ studies in chambers without water filtration showed $T_{90}$ to be as little as 2-3 hours. Lee et al. (2011), investigated whether the decay rates for $E$. coli were similar to halophilic and non-halophilic bacterial pathogens. For this purpose, they used 6 different pore size filters, namely $250 \mu \mathrm{m}$ (unfiltered), $0.7 \mu \mathrm{m}$ (for cleaning nanoflagellates and ciliates) and $0.02 \mu \mathrm{m}$ (for cleaning from any eventual predator). This design allowed the determination of the importance of protist bacterivory on bacterial decay in tropical coastal waters. According to these authors, E. coli is a poor indicator of halophilic pathogens, because they don't survive well in seawater. However, since these authors used culture methods, short survivorship might be a consequence of the non-cultivability. Sinton et al. (1999) carried out solar inactivation experiments in large chambers (300 L) in a so-called thermal jacket, 13,000 L in size, in order to improve the thermal homogenization of water. Besides sunlight assays, dark assays were carried out simultaneously, allowing the subtraction of the die-off results under dark conditions from those under sunlight conditions.

Presently, the advancement of molecular methods for strain detection and differentiation has led to a better understanding of the fates of, and changes in, microorganism communities in the environment (Kim and Wuertz, 2015; Korajkic et al., 2014). Omar (2010) looked for several gene targets, using PCR to encounter pathogenic and commensal E. coli in sewage effluents, and concluded that PCR has a large potential to be used for the monitoring of water samples for the presence of pathogenic E. coli without the need to culture the organisms. Zhang, $\mathrm{He}$, and Yan (2015), using cultivation-independent qPCR quantification of 16S rRNA genes and Next-Generation Sequencing (NGS), were able to analyze a microbial community. Korajkic et al. (2014) evaluated the effects of ambient sunlight and biotic interactions on the decay of culture-based Fecal Indicator Bacteria (FIB), and compared them to the application of molecular markers with qPCR using 1) Entero1a to target the Enterococcal 23S rRNA gene; 2) GenBac3 to target the Bacteroidales 16S rRNA gene; 3) HF183 to target the Human-associated Bacteroidales 16S rRNA gene; and 4) HumM2 to target the Bacteroidales-like putative $\sigma$ factor. These authors concluded that there was a strong correlation between molecular FIB and humanassociated genetic markers, but no correlation between any molecular markers and cultured FIB. This may be due to the greater persistence of the genetic marker in the environment. It may be that molecular markers could be used to trace sewage pollution farther than could cultured FIB. The molecular approach, then, could bring a new conceptual frame, free of the former culture methods and the confounding physiologic stages or differential decay of strains.

\subsection{Studies on VBNC (Viable But Not Cultivable) bacteria}

The hostile situations encountered by enteric bacteria in seawater lead to loss of the ability to form colonies and to grow on media, sometimes remaining viable (VBNC state; Xu et al., (1982)). Enteric bacteria can survive for long periods in fresh or salty water, as Viable But Not Cultivable (VBNC) organisms, a capability that is important because it allows them to retain their infectious ability. E. coli die-off measurements can be influenced by the presence of VBNC which is not accounted for, leading to underestimation of health risk for the modeling of outfalls and allowing direct human contact in contaminated waters (Bonamano et al., 2015; Gonzalez et al., 1992; Lothigius et al., 2010; Oliver et al. 2005; Omar, 2010; Pommepuy et al. 1996b, Rozen, 2001). Pommepuy et al. (1996b) have already proposed that most (maybe all) $E$. 
coli die-off attributed to sunlight could in fact be induction to the VBNC stage. Finally, an early study carried out by Gonzalez et al. (1992), using Rhodamine-stained bacteria (RSB), could straighten out this conceptual picture, enunciating that bacterial death should be understood as lysed bacteria that cannot grow on standard bacteriological media, cannot metabolize, and cannot infect other organisms. On the other hand, the VBNC, although injured, are active bacteria that have simply lost cultivability (Gonzalez et al., 1992, Lothigius et al., 2010). Thus, both Cultivable - Viable and VBNC bacteria are viviform cells and should also be counted in water-quality studies, monitoring and modeling (Omar, 2010).

Whenever studying VBNC bacteria, it is necessary to comprehend the differences in the counts obtained in various media. Generally, there are lower colony counts in more selective media like the Standard Levine BEM, and higher counts in less selective ones such as Nutrient Agar supplemented with sodium chloride (Gauthier et al, 1987; Pommepuy et al., 1996a). Even in less-selective media, up to $30 \%$ of the bacteria do not grow, because of the presence of VBNC (Taimur-Khan et al., 2010). Enzymatic assays, based on the detection of the enzymes $\beta$ galactosidase - characteristic of the Coliform group, and $\beta$-glucuronidase - characteristic of $E$. coli, can disclose the presence of cells even after they have lost their colony-forming capacity (Davies et al. 1995; Nataro and Kaper, 1998; Pommepuy et al., 1996a).

There are other techniques that produce reliable but differing results from cultures, like flow cytometry counts, and epifluorescence microscopy (Beardsley et al., 2003; Pommepuy et al., 1996b; Taimur-Khan et al. 2010; Troussellier et al., 1998), which are worth applying in decay studies. For example, Pommepuy et al., (1996b) evaluated E. coli decay in flasks and chambers. After 26 hours they obtained stable direct counts - from flasks - by epifluorescence microscopy plus acridine orange stain, while measurements on spread culture methods obtained no detectable count. Dark assays did not show significant decreases in culture measurements (as agreed by Troussellier et al. (1998). These results showed that solar radiation impacts culture counts, but not bacterial viability. All these findings demonstrate the effects of the chosen methodologies on the results, but also weakens solar radiation disinfection theory, and can reinforce the conclusions of Pommepuy et al., (1996b) that in many cases, the die-off attributed to natural sunlight may actually mean that cells become VBNC rather than experiencing a definitive die-off or cell death.

\subsection{The scale of the studies}

In order to assess $E$. coli $T_{90}$, researches have been employing an inoculum of bacteria accounting of $10^{6}-10^{9} \mathrm{CFU} / 100 \mathrm{~mL}$ on assays, where decay is used for the establishment of mathematical expressions (Alkan, 1999; Alkan et al., 1995; Chan et al., 2015; Lothigius et al., 2010; Moriñigo et al.; 1990) These techniques are performed in microcosm- or mesocosm-scale experiments in the field or under laboratory conditions, but can also be carried out in field monitoring surveys. Rozen (2001) draws attention to the limitations of both field and laboratory experiments: the laboratory experiments cannot simulate the environmental complexity; field studies, used to validate laboratory results, yield site-specific data; and field monitoring surveys lack target population control: most of them ignore the previous growth history of the strains. The studies range from well-controlled systems, yielding superficial knowledge to complex systems in which processes cannot be adequately controlled, and hence may not produce valid results. Thus, to overcome these limitations, consideration of the appropriate scale is required, consistent with what can be expected. It should be understood that any experimental design can give only partial and imprecise information.

Laboratory microcosm-scale experiments have been widely employed and have attained significant improvements in $T_{90}$ knowledge. After Carpenter (1996), this scale has been used to estimate the response of organisms - in terms of decay velocity, replicability and power 
increment - to specific environmental conditions. Microcosm scales have been built with bottles, beakers, flasks or columns, equipped with lamps, under very controlled conditions (Carpenter, 1996; Craig et al. 2004; Jozić et al., 2014; Lothigius et al., 2010; Pommepuy et al., 1996b; Zhang et al., 2015). However, the microcosm treatments can significantly alter the features of communities and ecosystems. Microcosms, then, can be considered a very indirect way of learning about the ecology, but can yield misleading results concerning environmental processes (Beardsley et al., 2003; Carpenter, 1996; Davies-Colley et al., 1994).

Mesocosm is another form that can precede ecological assays. It can be structured as an experimental outdoor plot or as an "in situ" partially closed environment, with limited exchanges with its surroundings (Kampichler et al., 2001). Mesocosms differ from microcosms in their fundamental concepts. The arrangement of a mesocosm allows assay control, without the mentioned limitations and confounding factors from microcosms, and has been used by many authors (Davies et al., 1995; Forster and Schubert, 2001; Moriñigo et al., 1990; Pommepuy, et al., 1996b; Rhodes, 1988; 1990). However, mesocosms cannot provide full access to real aquatic ecosystems, promoting both bacterial species' selective growth and grazing, distorting the community structure (Beardsley et al., 2003). For example, Forster and Schubert (2001) used a robust $1-\mathrm{m}^{3}$ mesocosm to test the effects of enhanced and reduced ultraviolet radiation (UV) on the planktonic community. These authors encountered smaller zooplankton population densities (rotifers and Copepods) that increased rapidly to populations that were denser than those observed in the estuary, probably due to the absence of predators like fish and larger zooplankton. Therefore, in order to study E. coli T90 under near-real conditions, the mesocosm should comprise closed containers located in the real environment, avoiding loss of cells or mixing with environmental constituents, but still allowing fluxes. Some authors (Davies et al., 1995; Moriñigo et al., 1990; Pommepuy et al., 1996b; Rhodes, 1988) tried to solve these technical limitations using diffusion chambers (as modified by McFeters and Stuart (1972) with $0.2 \mu \mathrm{m}$ polycarbonate membranes to interface with the environment. Other authors showed that dialysis bags ( 13 to $14 \mathrm{kDa}$ pore-size) could attain still-better results (Beardsley et al., 2003; Korajkic et al., 2014). These chambers allow dissolved matter, but no cells, to pass through them.

\subsection{Modeling}

The literature includes several models that simulate $E$. coli $T_{90}$ die-off in the laboratory and in environmental marine conditions. Alkan et al. (1995) constructed a model considering five influences: light $\left(\mathrm{W} \mathrm{m}^{-2}\right)$, turbidity (absorbance), sewage load $(\% \mathrm{v} / \mathrm{v})$, mixing $\left(\mathrm{cm}^{2} \mathrm{~s}^{-1}\right)$ and temperature $\left({ }^{\circ} \mathrm{C}\right)$. However, multiple regressions explained only $76 \%$ of the cultivated $E$. coli die-off, and the authors concluded that the limited accuracy may be the result of the experimental conditions. Feitosa et al. (2013a) made a statistical evaluation of several models and recommended the one designed by Mancini (1978), which presented the most reliable result when compared to others. This model includes the decay rate $(\mathrm{K})$ in the presence and absence of solar radiation, and combines the salinity and temperature actions. Feitosa et al. (2013b) coupled Mancini's decay equation in hydrodynamic models, and found strong correlations between fecal coliform concentrations and solar radiation levels. In addition, in order to attain better reliability, the modeling studies have been optimized in field surveys, which calibrated marine currents, tides, wind or added particulate matter, attached and free bacteria settling, and advection/diffusion variables. Several of these models can be examined in the literature (e.g., Chan et al., 2015; Fernández, 2011). Chan et al., (2015) used the same environmental factors as Mancini's, resulting in good accuracy with field data. Rodrigues et al. (2011) coupled a threedimensional hydrodynamic and fecal contamination model, and were able to represent the main patterns and trends observed in E. coli and fecal Enterococcus concentrations along a stream. Zhu et al. (2011) concluded that efflux from sand during high tide was responsible for the 
concentrations of indicator microbes. Regardless of the success of these models, it must be taken into account that these results might be distorted by the modeling procedures and the chosen monitoring fecal indicators employed, which were limited by the physiologic state, as mentioned above.

\section{FACTORS AFFECTING POPULATION DECAY}

\subsection{Solar radiation}

A large number of studies have assessed the importance of solar radiation on E. coli $T_{90}$ under natural conditions (e.g., Hernroth et al., 2010; Herrig et al., 2015; Korajkic et al., 2013). Jozić et al. (2014) tested two different E. coli strains, from canine (ATCC 36218) and human (ATCC 8739) feces, and found strong and significant effects of solar radiation, reducing the $T_{90}$ by 15 - to 70 -fold. These authors also observed that UV declined by around $9 \%$ to $2 \%$ per meter of depth with a proportional increase in $T_{90}$, principally at 320- to 360-nm wavelengths. This wavelength range was shown to have the highest impact on bacterial survival (Davies-Colley et al., 1994). Sinton et al. (1999) found that cultivable E. coli decayed 29 times faster under solar radiation than under dark conditions. Craig et al. (2004) assessed cultivable E. coli counts between 10 and 100 times smaller from seawater under sunlight than from bottom sediments, two days after a storm event. Considering these data, the $T_{90}$ from oligotrophic areas should not be applied in eutrophic ones, where plankton and suspended solids reduce the lower wavelength of sunlight, principally UV-B (Rozen, 2001). Confirming this behavior, Alkan et al. (1995) observed the highest cultivable E. coli die-off when the sewage was diluted to $0.25 \%$ under 900 $\mathrm{W} / \mathrm{m}^{2}$, and the absorbance attained a rate of 0.04 , its lowest assays value. Herrig et al. (2015) developed a model made for water-quality simulations in the Lahn River, resulting in a strong correlation between turbidity and fecal indicators, probably because of the reduced solar radiance in that area. Along these same lines, Craig et al. (2004) attributed differences between modeled and measured values of coliform die-off to varying turbidity after storm events. Thus, where irradiance is important, the turbidity factor is important also, and has been considered a dominant predictor for $T_{90}$ on enteric bacteria and somatic coliphages (Hernroth et al., 2010; Herrig et al., 2015; Kay et al., 2005).

\subsection{Salinity}

Because salinity increases osmotic potential of the water, coliform bacteria are strongly affected. However, the effects of salinity is not only osmotic, but interacts with other parameters. Troussellier et al. (1998) highlighted the importance of the interactions of nutrient deprivation and salinity, while Sinton et al. (1999) observed that the solar radiation inactivation (making bacteria VBNC) increased when the salinity was high. These works agree with those of Yang et al. (2000). Lothigius et al. (2010), who, when working with enterotoxigenic E. coli during long-term incubation (up to 6 months), encountered a large difference ( 2 weeks) in cultivability between seawater and freshwater. Jozić et al. (2014) also obtained significantly different results, demonstrating that E. coli decay is linked to salinity, although this author used a narrow salinity range.

The pre-adaptation to high osmolarity would up-shift the cell resistance to seawater salinity, because during osmotic shock, a bacterial cell starts to accumulate osmoprotectant molecules (Gauthier et al., 1987, Rozen 2001). Confirming these results, de Brauwere et al. (2014a) measured strong $E$. coli decay in a river sector where salinity changes were pronounced. Other authors showed that salinity seems to synergistically influence E. coli decay, an effect that, along with other parameters, will be further discussed in following sections of this article. 


\subsection{Dilution}

Dilution was indicated as one of the most important factors influencing $E$. coli decay in the Scheldt River and estuary (de Brauwere et al., 2014a). The effects of solar radiation, turbidity, salinity and predation are modified by dilution (Alkan et al., 1995; Yang et al., 2000). Yang et al. (2000), highlighted that dilution is important not only because it reduces the sewage concentration, but also because:

a) In seawater, the salinity of sewage increases, thereby increasing its deleterious influence over bacteria

b) Elevated concentrations of suspended solids increase turbidity, which reduces the penetration and action of solar radiation in sewage. Dilution restores the radiation penetration, increasing mortality of the bacteria.

c) Dilution causes predators to disperse in the sewage mixture, reducing predation pressure.

\subsection{Temperature}

Although temperature is often cited as an important factor for bacteria, it was excluded from the model of Herrig et al. (2015), because these authors considered that temperature depends on solar radiance. Jozić et al. (2014), carried out regression analyses and found no significant influence of temperature, even when interacting with salinity. Alkan et al. (1995) and Brooks et al. (2015) encountered no significant effect of temperature on the persistence of cultivable E. coli and Enterococcus sp. Thus, many authors have given little importance to the effect of temperature oscillations on $T_{90}$ values (Alkan et al., 1995). On the other hand, Mackay (1985) pointed that high temperatures inactivate bacteria, and promote increased metabolism, which requires extra sources of nutrients.

Hernroth et al. (2010) encountered a better performance of ETEC (Entero-Toxigenic $E$. coli) cultivated at $8^{\circ} \mathrm{C}$ compared to $18^{\circ} \mathrm{C}$, agreeing with Craig et al. (2004), who worked at $10^{\circ} \mathrm{C}$, $20^{\circ} \mathrm{C}$ and $30^{\circ} \mathrm{C}$. It should be also considered that Rhodes (1988) evidenced significant effects of temperatures greater than $10^{\circ} \mathrm{C}$, on $E$. coli multiplication; the higher temperatures reduced its net die-off, in assays. Finally, Blaustein et al. (2013) reviewed 166 datasets on E. coli survival under dark conditions, and found an increasing trend of inactivation values following temperature increase. The role of temperature might be considered synergistically with nutritional aspects. In both cases, to manage systems or model water quality, it is very important to consider the local temperature conditions.

\subsection{Nutrient availability}

Nutritional availability seems to play a key role in the viability of $E$. coli in the environment. The existence of readily usable nutrients and the way the bacteria use them will determine the period the bacteria will remain viable (e.g., Gauthier et al., 1987; Hernroth et al., 2010). The nutritional status works synergistically with other factors. For example, Hernroth et al., (2010) analyzed ETEC cultivated at $18^{\circ} \mathrm{C}$ in highly nutritional water, and observed a significant positive effect on its cultivability, compared to cultivation in low-nutritional water. In fact, nutritional conditions could promote population increase (Rhodes, 1988). Besides, Carrillo et al. (1985) concluded that the primary regulator of densities of coliforms in the tropical environment is probably the nutrient concentration. However, under nutritional stress, E. coli can modulate its physiology to conserve energy or to use nutrients released from dying cells (Bucci et al., 2011). Knowledge of the nutritional requirements and their implications on research under laboratory conditions that use cultivated inoculum is relevant. However, nutritional mechanisms are also controlled by genetic modulations, which will be discussed in following sections.

\section{IPABH}

Rev. Ambient. Água vol. 13 n. 4, e2106 - Taubaté 2018 


\subsection{Interactions with solids}

The resuspension process is an emerging issue, and an important gap in bacterial environmental decay research, linking adsorption, desorption, viability and the infectivity capacity of E. coli bacteria (Korajkic et al., 2013; Steets and Holden, 2003; de Brauwere et al., 2014a). Using a sedimentation column, Alkan (1999) studied the relationship between particles and bacteria, observing that the concentration of clay particles, the shear rate, and the concentration of sewage, had significant roles in the removal of $E$. coli from the water column (up to 36\%). Nevertheless, this removal was not linear, because although on the one hand the bacteria associate with the particles, sinking together, on the other hand, sewage particles compete with bacteria for adsorption sites on the particles. In his study, the principal removal of $E$. coli occurred through a shear rate of $25 \mathrm{~s}^{-1}$ at a concentration of $60 \mathrm{mg} \mathrm{L}^{-1}$ clay and $0.5 \%$ sewage content. The authors concluded that bacteria removal in the sea becomes significant when shear rates vary between 20 and $25 \mathrm{~s}^{-1}$ and with turbidities of up to $50 \mathrm{mg} \mathrm{L}^{-1}$. Considering that many outfalls are modeled with an initial sewage dilution of $1 \%$ (1), the highest removal rate could take place in the mixing zones. It can be inferred that the removal of bacteria by solids will be important principally in restricted coastal areas with both high turbidity and high shear rates.

Another point to be considered is the relationship between E. coli and suspended solids associated with adsorption/desorption and precipitation/resuspension processes. Adsorption can occur dramatically in short intervals after storm events leading to the removal of bacteria from the water column. In sediments, bacteria are protected against ultraviolet radiation and present concentrations significantly different from those in the water column (Craig et al., 2004). de Brauwere et al. (2014a), used a mixed bacterial condition in the Scheldt River and Estuary model (free, attached and bottom-settled bacteria) and observed that bacteria presented different die-off rates, and that free-stage bacteria presented higher decay rates than adsorbed ones. These findings reproduced reality because they achieved good fitting (or agreement) with field data. On the bottom, the cells remain protected from solar radiation, but are exposed to competition from native microbiota and are subjected to the effects of other precipitated pollutants (like heavy metals). The temperature, biotic relations and nutritional conditions are also different. The newly settled layer formed by solids covers the former bacteria that might be still viable and available for a re-suspension process. Resuspended bacteria can be a longterm source of contamination for the water column, mainly after storm events, and they must be considered in management systems and water-quality models. And finally, adsorption processes' binding properties between the bacteria and particles are highly dependent on the size and composition of the particles. These features highlight the importance of considering regional sediment characteristics and dynamics before defining the methodology for any study of bacterial decay (Abessa et al., 2005; Craig et al., 2002; 2004; Crump, 1996). The presently available results reinforce the importance of outlining outfall plumes that avoid contamination of sandy beaches and bottom sediments.

\subsection{Predation}

Although several die-off models have omitted the predation of E. coli, some authors have highlighted its importance. Lothigius et al. (2010), using sterile water with no predation did not encounter any significant decay in cultivable ETEC from either seawater or freshwater until after 48 hours, in a laboratory microcosm. Bacterial decay began at that time. Davies et al. (1995) encountered an important impact of predation on fecal coliforms in beach sediments, and Rhodes (Rhodes, 1988; 1990) encountered a significant impact of natural microbiota on $E$. coli die-off in an estuarine microcosm. Korajkic et al. (2013) found that the magnitude of the decay was significantly greater in the water columns of both fresh and seawater, when 
indigenous microbiota was present (natural assay). By contrast, when assays were performed using freshwater and cycloheximide - which aimed to eliminate protozoan predators - there were die-off rates approximately one order of magnitude lower than natural assay. Several authors have concluded that predation by protozoa - particularly, the nanoflagellates - is a significant biotic factor affecting bacterial development in natural environments (Beardsley et al., 2003; Gonzalez et al., 1992; Rozen, 2001). Crump (1996) consider rotifers and small ciliates as possible bacterial predators. This reinforces the above-mentioned results of Korajkic et al. (2013), which suggested that interactions with non-protozoan microbiota also affect $E$. coli survival.

Yang et al. (2000) studied the interactions between cultivable bacteria decay and three factors: salinity, light intensity and dilution (seawater/wastewater). In the absence of predation, light caused $90 \%$ of the decay rate. However, in the presence of predators, the light+salinity+dilution combination contributed to only $50 \%$ of the population decay rate. However, Korajkic et al. (2014) observed that E. coli did not seem impacted by indigenous microbiota in in situ Mississippi mesocosms. It was also observed that there was little E.coli increase after 120 hours under no indigenous microbiota, plus solar radiation assays.

In light of the above-described results, we can argue whether the practice of removing microbiota from sewage to carry out $T_{90}$ decay experiments is appropriate. It is further important to consider that decay results from autoclaved sewage assays should account for the effects of lack of predation and possible changes in chemical compounds. An alternative method to autoclaving for comparison assays would be to use a $0.22-\mu \mathrm{m}$ filter to exclude microbiota and produce sterile natural water samples (e.g., Abessa et al., 2005; Hernroth et al., 2010).

\subsection{Resistance variations at the gene-expression level}

Since researchers have drawn attention to environmental stress resistance, it has become important to consider the molecular mechanisms involved. Studies have identified that starvation induces cross-resistance to both osmotic and heat stress, and even a strong general resistance to environmental stressors. The overall response to stress is mediated by $\operatorname{RpoS}(\sigma)$ genes, which increases or decreases in specific culture growth rate. The RpoS $\sigma$ ) transcription factor controls many genes involved in responses to several types of stresses, such as starvation, osmotic stress, acid shock, thermal shock, and oxidative damage, which can shift bacteria to a stationary phase (Berney et al., 2006; Jenkins et al., 1990; Rozen, 2001; Siegele, 1992; van Elsas et al., 2011). On the other hand, $\operatorname{RpoS}(\sigma)$ is regulated by ppGpp, the global genetic regulator in E. coli (Magnusson et al., 2005), through complex transcriptional switching (Sharma and Chatterji 2010). This leads bacteria to change their physiology or their phenotypes (Berney et al., 2006; van Elsas et al., 2011).

van Elsas et al. (2011) found that the availability of carbon substrates is probably the main critical factor that controls the persistence of $E$. coli in the environment, a result that is in agreement with ecological surveys (Carrillo et tal., 1985; Craig et al., 2004; Crump, 1996). Berney et al. (2006) observed that nutritional status directly affects the cell growth phase and the medium composition, conditions that in turn affect the expression of E. coli heat shock proteins (HSPs). These authors also observed that oxygen concentration in broth cultures declined as bacterial growth proceeded, leading to an eventual decrease in bacterial growth. It is therefore very important to precisely control (i.e., standardize) the growth rate, for which Berney et al. (2006) suggested an inoculum with a $\mu$ (Population growth) $=0 \mathrm{~h}^{-1}$ for stationaryphase cells.

Several in situ surveys concerning the sanitation quality of the environment have underlined the significance of gene expression. The $E$. coli $T_{90}$ from raw sewage was shorter than that from waste stabilization ponds previously exposed to sunlight (Sinton et al., 1999), a difference that can be attributed to higher resistance of the latter. Jozić et al. (2014) found that 
E. coli cultivated under stressful environmental conditions decay three times slower than their first generation taken directly from, and then isolated from, the sea. The authors concluded that there are varying mechanisms acting within the cell to provide environmental bacterial protection. The practical concerns of these findings are that gene expression can improve the differential survival of different strains under the same environmental conditions (Bucci et al., 2011; Zhang et al., 2015). Further genetic studies that may affect $T_{90}$ should be carried out, looking for virulent and persistent strains. The understanding of these processes is important for both health and public safety reasons.

\section{CONCLUSIONS}

For the last three decades, much more bacteriological knowledge has been accumulated, yet gaps in bacterial decay modeling remain. The existence of a group of decay models providing a good representation of the sanitation quality of the environment, from several locations worldwide, is witness to the efforts spent on this kind of research. Apparently, these models work fine; but the question is "What are they modeling?" In this review, we saw that models are considering viable $E$. coli to be still cultivable, excluding viable but not cultivable (VBNC) cells.

UV radiation seems to be the most important factor inducing the VBNC state in $E$. coli bacteria. However, the most-applied methods for the evaluation of colimetry do not consider these viable cells, which is a major issue, considering that most results on colimetry are underestimated. VBNC cells cannot be cultivated in vitro, but they can be active in the environment.

The presence of turbidity in the water column may also affect the influence of UV radiation. Hence, it is expected that degraded eutrophicated environments will tend to display longer $T_{90}$ periods, increasing health issues.

We have shown that salinity and dilution can affect decay, because osmotic pressure in saline systems may kill bacteria. However, slow dilution may promote a gradual decrease in salinity, that engenders increasing preadaptation to the new osmotic pressure, so that if the amount of sewage is too large, as in large outfalls, $T_{90}$ may be severely increased. In this dilution process, temperature can also be modified; however, we have shown that $E$. coli is little affected by this parameter. And temperature may play a more important role when associated with variations in nutrient concentrations.

Because they are associated with suspended particles, bacteria can be removed from the water column through settling, and may find a suitable environment within the sediments, where nutrients are abundant, UV radiation hardly penetrates, and temperatures are more constant. Sediment may then function as a source of bacteria to the water column during resuspension processes, as during storm events.

Concerning the biological aspects, we discussed predation as a factor reducing $T_{90}$ values, and showed that many researchers, mainly modelers, disagreed, claiming it to be irrelevant compared to other factors. Although a review of the literature showed that in many situations predation may be relevant, it has been excluded from the experiments because their water is autoclaved, killing any possible predator. Including predators in laboratory experiments is a difficult task because results become more complex and random; however, considering its importance, it should be more frequently considered.

Finally, we discussed some aspects of the genetics of $E$. coli in the environment, in the light of emerging tools. It was interesting to note inductions in the genetic expressions as a function of environmental stresses like starvation, and osmotic and thermal stress. These "induced" phenotype modifications may be marked in populations subjected to increasing 
stress, and these populations may be developing environmental resistances. $T_{90}$ values in these adapted bacteria are expected to be much longer than in bacteria coming out of outfalls

The knowledge of factors affecting $E$. coli allowed the development of new methodologies and new decay models that give more accurate and reliable information. With this new information, the researchers have been able to establish new management procedures that reduce the survival rates in the natural environment. Such procedures are important, because as coastal human populations continue to increase, bacterial loads are also increasing, despite sewage-treatment efforts.

As discussed throughout in this paper, there are many parameters that affect E. coli decay rates, many of them have been disclosed from field studies and many have been observed in in vitro experiments, both with clear limitations. Researchers should therefore consider associated field and in vitro experiments, considering that different locations may induce different behaviors of these important bacteria.

\section{ACKNOWLEDGEMENTS}

The authors are grateful for CNPq and Post-Graduation Program in Sustainable Systems Management for financial support (CNPq grant \# 306714/2013-2).

\section{REFERENCES}

ABESSA, D. M.; CARR, R. S.; RACHID, B. R.; SOUSA, E. C.; HORTELANI, M. A.; SARKIS, J. E. Influence of a Brazilian sewage outfall on the toxicity and contamination of adjacent sediments. Marine Pollution Bulletin, v. 50, n. 8, p. 875-885, 2005. https://dx.doi.org/10.1016/j.marpolbul.2005.02.034

ALKAN, U. The fate of enteric bacteria in relation to suspended particles in seawater. Water and Environment Journal - CIWEM, v. 13, n. 1, p. 16-23, 1999.

ALKAN, U.; ELLIOTT, D. J.; EVISON, L. M. Survival of enteric bacteria in relation to simulated solar radiation and other environmental factors in marine waters. Water Research, v. 29, n. 9, p. 2071-2081, 1995.

ARAUJO, C. F.; SILVA, D. M.; CARNEIRO, M. T.; RIBEIRO, S.; FONTANA-MAURELL, M.; ALVAREZ, P. Detection of Carbapenemase genes in aquatic environments in Rio de Janeiro, Brazil. Antimicrobial Agents Chemotherpy, v. 60, n. 7, p. 4380-4383, 2016. https://dx.doi.org/10.1128/AAC.02753-15

BEARDSLEY, C.; PERNTHALER, J.; WOSNIOK, W.; AMANN, R. Are readily culturable bacteria in coastal North Sea waters suppressed by selective grazing mortality? Applied and Environmental Microbiology, v. 69, n. 5, p. 2624-2630, 2003. https://dx.doi.org/10.1128/aem.69.5.2624-2630.2003

BERNEY, M.; WEILENMANN, H. U.; IHSSEN, J.; BASSIN, C.; EGLI, T. Specific growth rate determines the sensitivity of Escherichia coli to thermal, UVA, and solar disinfection. Applied Environmental Microbiology, v. 72, v. 4, p. 2586-2593, 2006. https://dx.doi.org/10.1128/AEM.72.4.2586-2593.2006

BLAUSTEIN, R. A.; PACHEPSKY, Y.; HILL, R. L.; SHELTON, D. R.; WHELAN, G. Escherichia coli survival in waters: Temperature dependence. Water Research, v. 47, n. 3, p. 569-578, 2013. 
BONAMANO, S.; MADONIA, A.; BORSELliNO, C.; STEFANI, C.; CARUSO, G.; PASQUALE, F. de et al. Modeling the dispersion of viable and total Escherichia coli cells in the artificial semi-enclosed bathing area of Santa Marinella (Latium, Italy). Marine

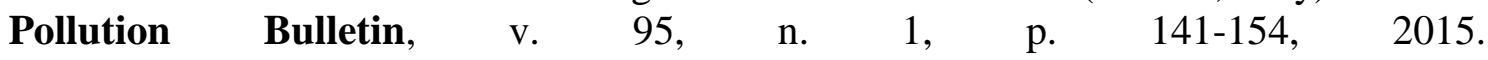
https://dx.doi.org/10.1016/j.marpolbul.2015.04.030

BROOKS, Y.; ASLAN, A.; TAMRAKAR, S.; MURALI, B.; MITCHELL, J.; ROSE, J. B. Analysis of the persistence of enteric markers in sewage polluted water on a solid matrix and in liquid suspension. Water Research, v. 76, n. 1, p. 201-212, 2015. https://dx.doi.org/10.1016/j.watres.2015.02.039

BUCCI, V.; VULIĆ, M.; RUAN, X.; HELLWEGER, F. L. Population dynamics of Escherichia coli in surface water1. Journal of the American Water Resources Association, v. 47, n. 3, p. 611-619, 2011. https://dx.doi.org/10.1111/j.1752-1688.2011.00528.x

CARNEIRO, M.; SILVA, D.; CHAGAS, T.; ZAHNER, V.; ASENSI, M.; HAGLER, A. Bioindicadores complementares à colimetria na análise da qualidade da água: o potencial das leveduras no Lago Juturnaíba/RJ. Sistemas \& Gestão, v. 10, n. 3, p. 542-552, 2015. https://dx.doi.org/10.7177/sg.2015.v10.n3.a15

CARPENTER, S. R. Microcosm experiments have limited relevance for community and ecosystem ecology. Ecology, v. 77, n. 3, p. 677-680, 1996.

CARRILlO, M.; ESTRADA, E.; HAZEN, T. C. Survival and enumeration of the fecal indicators Bifidobacterium adolescentis and Escherichia coli in a tropical rain forest watershed. Applied Environmental Microbiology, v. 50, n. 2, p. 468-476, 1985.

CHAN, Y. M.; THOE, W.; LEE, J. H. W. Field and laboratory studies of Escherichia coli decay rate in subtropical coastal water. Journal of Hydro-environment Research, v. 9, n. 1, p. 1-14, 2015. https://dx.doi.org/10.1016/j.jher.2014.08.002

CRAIG, D. L.; FALLOWFIELD, H. J.; CROMAR, N. J. Use of microcosms to determine persistence of Escherichia coli in recreational coastal water and sediment and validation with in situ measurements. Journal of Applied Microbiology, v. 96, n. 5, p. 922-930, 2004. https://dx.doi.org/10.1111/j.1365-2672.2004.02243.x

CRAIG, D. L.; FALLOWFIELD, H. J.; CROMAR, N. J. Enumeration of faecal coliforms from recreational coastal sites. Evaluation of techniques for the separation of bacteria from sediments. Journal of Applied Microbiology, v. 93, n. 4, p. 557-565, 2002.

CRUMP, B. B. Particle-attached bacteria and heterotrophic plankton associated with the Columbia River estuarine turbidity maxima. Marine Ecology Progress Series, v. 138, n. 23, p. 265-273, 1996.

DAVIES-COLLEY, R. J.; BELL, R. G.; DONNISON, A. M. Sunlight inactivation of enterococci and fecal coliforms in sewage effluent diluted in seawater. Applied Environmental Microbiology, v. 60, n. 6, p. 2049-2058, 1994.

DAVIES, C. M.; APTE, S. C.; PETERSON, S. M. $\beta$-D-galactosidase activity of viable, nonculturable coliform bacteria in marine waters. Letters in Applied Microbiology, v. 21, n. 2, p. 99-102, 1995.

DAVIES, C. M.; LONG, J. A.; DONALD, M.; ASHBOLT, N. J. Survival of fecal microorganisms in marine and freshwater sediments. Applied Environmental Microbiology, v. 61, n. 5, p. 1888-1896, 1995. 
DE BRAUWERE, A.; GOURGUE, O.; DE BRYE, O.; SERVAIS, P.; OUATTARA, N. K.; DELEERSNIJDER, E. Integrated modelling of faecal contamination in a densely populated river-sea continuum (Scheldt River and Estuary). Science of the Total $\begin{array}{lllll}\text { Environment, } & \text { v. } & 468-469, & \text { p. } & 31-45,\end{array}$ https://dx.doi.org/10.1016/j.scitotenv.2013.08.019

DE BRAUWERE, A.; OUATTARA, N. K.; SERVAIS, P. Modeling Fecal Indicator Bacteria Concentrations in Natural Surface Waters: A Review. Critical Reviews in Environmental Science and Technology, v. 44, n. 21, p. 2380-2453, 2014b. https://dx.doi.org/10.1080/10643389.2013.829978

FEITOSA, R. C.; ROSMAN, P. C.; CARVALHO, J. L.; CORTES, M. B.; WASSERMAN, J. C. Comparative study of fecal bacterial decay models for the simulation of plumes of submarine sewage outfalls. Water Science and Technology, v. 68, n. 3, p. 622-631, 2013a. https://dx.doi.org/10.2166/wst.2013.286

FEITOSA, R. C.; ROSMAN, P. C.; BLENINGER, T.; WASSERMAN, J. C. Coupling bacterial decay and hydrodynamic models for sewage outfall simulation. Journal of Applied Water Engineering and Research, v. 1, n. 2, p. 137-147, $2013 \mathrm{~b}$. https://dx.doi.org/10.1080/23249676.2013.878882

FERNÁNDEZ-DELGADO, M.; SUÁREZ, P. Multiple antibiotic resistances of enteric bacteria isolated from recreational coastal waters and oysters of the Caribbean Sea. Annals of Microbiology, v. 59, n. 3, p. 409-414, 2009.

FERNÁNDEZ, F. 3D lagrangian modeling of Montevideo's submarine outfall plume. In: INTERNATIONAL SYMPOSIUM ON OUTFALL SYSTEMS, 2011, Mar del Plata, Argentina. Proceedings... Mar del Plata: IAHR/IWA, 2011.

FORSTER, R. M.; SCHUBERT, H. The effects of ultraviolet radiation on the planktonic community of a shallow, eutrophic estuary: results of mesocosm experiments. Helgoland Marine Research, v. 55, n. 1, p. 23-34, 2001. https://dx.doi.org/10.1007/s101520000058

GAUTHIER, M. J.; MUNRO, P. M.; MOHAJER, S. Influence of salts and sodium chloride on the recovery of Escherichia coli from seawater. Current Microbiology, v. 15, p. 5-10, 1987.

GONZALEZ, J. M.; IRIBERRI, J.; EGE, L.; BARCINA, I. Characterization of culturability, protistan grazing, and death of enteric bacteria in aquatic ecosystems. Applied and Environmental Microbiology, v. 58, n. 3, p. 998-1004, 1992.

GRIFFITH, J. F.; WEISBERG, S. B.; ARNOLD, B. F.; CAO, Y.; SCHIFF, K. C.; COLFORD JR., J. M. Epidemiologic evaluation of multiple alternate microbial water quality monitoring indicators at three California beaches. Water Research, v. 94, p. 371-381, 2016. https://dx.doi.org/10.1016/j.watres.2016.02.036

HERNROTH, B.; LOTHIGIUS, A.; BOLIN, I. Factors influencing survival of enterotoxigenic Escherichia coli, Salmonella enterica (serovar Typhimurium) and Vibrio parahaemolyticus in marine environments. FEMS Microbiological Ecology, v. 71, n. 2, p. 272-280, 2010. https://dx.doi.org/10.1111/j.1574-6941.2009.00803.x

HERRIG, I. M.; BOER, S. I.; BRENNHOLT, N.; MANZ, W. Development of multiple linear regression models as predictive tools for fecal indicator concentrations in a stretch of the lower Lahn River, Germany. Water Research, v. 85, p. 148-157, 2015. https://dx.doi.org/10.1016/j.watres.2015.08.006 
JENKINS, D. E.; CHAISSON, S. A.; MATIN, A. Starvation-induced cross protection against osmotic challenge in Escherichia coli. Journal of Bacteriology, v. 172, n. 5, p. 27792781, 1990.

JOZIĆ, S.; MOROVIĆ, M.; SOLIC, M.; ORDULJ, M. Effect of solar radiation, temperature and salinity on the survival of two different strains of Escherichia coli. Fresenius Environmental Bulletin, v. 23, n. 8, p. 1852-1859, 2014.

KAMPICHLER, C.; BRUCKNER, A.; KANDELER, E. Use of enclosed model ecosystems in soil ecology: a bias towards laboratory research. Soil Biology and Biochemistry, v. 33, n. 3, p. 269-275, 2001.

KAY, D.; STAPLETON, C. M.; WYER, M. D.; MCDONALD, A. T.; CROWTHER, J.; PAUL, N. et al. Decay of intestinal enterococci concentrations in high-energy estuarine and coastal waters: towards real-time T90 values for modelling faecal indicators in recreational waters. Water Research, v. 39, n. 5, p. 655-67, 2005.

KIM, M.; WUERTZ, S. Survival and persistence of host-associated Bacteroidales cells and DNA in comparison with Escherichia coli and Enterococcus in freshwater sediments as quantified by PMA-qPCR and qPCR. Water Research, v. 87, p. 182-192, 2015. https://dx.doi.org/10.1016/j.watres.2015.09.014

KORAJKIC, A.; MCMINN, B. R.; SHANKS, O. C.; SIVAGANESAN, M.; FOUT, G. S.; ASHBOLT, N. J. Biotic interactions and sunlight affect persistence of fecal indicator bacteria and microbial source tracking genetic markers in the upper Mississippi river. Applied and Environmental Microbiology, v. 80, n. 13, p. 3952-3961, 2014. https://dx.doi.org/10.1128/AEM.00388-14

KORAJKIC, A.; WANJUGI, P.; HARWOOD, V. H. Indigenous microbiota and habitat influence Escherichia coli survival more than sunlight in simulated aquatic environments. Applied and Environmental Microbiology, v. 79, n. 17, p. 5329-5337, 2013. https://dx.doi.org/10.1128/AEM.01362-13

LEE, C. W.; NG, A. Y. F.; BONG, C. W.; NARAYANAN, K.; SIM, E. Ui W.; NG, C. C. Investigating the decay rates of Escherichia coli relative to Vibrio parahemolyticus and Salmonella Typhi in tropical coastal waters. Water Research, v. 45, n. 4, p. 1561-1570, 2011. https://dx.doi.org/https://doi.org/10.1016/j.watres.2010.11.025

LOTHIGIUS, A.; SJOLING, A.; SVENNERHOLM, A. M.; BOLIN, I. Survival and gene expression of enterotoxigenic Escherichia coli during long-term incubation in sea water and freshwater. Journal of Applied Microbiology, v. 108, n. 4, p. 1441-1449, 2010. https://dx.doi.org/10.1111/j.1365-2672.2009.04548.x

MACKAY, D. W. Bacterial Mortality. In: GAMESON, A. L. H.; GOULD, J. (Eds.). Investigations of sewage discharges to some British coastal waters. Medmenham: Water Research Centre, 1985.

MAGNUSSON, L. U.; FAREWELL, A.; NYSTROM, T. ppGpp: a global regulator in Escherichia coli. Trends in Microbiology, v. 13, n. 5, p. 236-242, 2005.

MANCINI, J. L. Numerical estimates of coliform mortality rates under various conditions. Journal of the Water Pollution Control Federation, v. 50, n. 11, p. 2477-2484, 1978.

MCFETERS, G. A.; STUART, D. G. Survival of coliform bacteria in natural waters: field and laboratory studies with membrane-filter chambers. Applied Microbiology, v. 24, p. 805$811,1972$. 
MORIÑIGO, M. A.; CORNAX, R.; CASTRO, D.; MARTINEZ-MANZANARES，E.; BORREGO, J. J. Viability of Salmonella spp and indicator microorganisms in seawater using membrane diffusion chambers. Antonie van Leeuwenhoek, v. 57, p. 109-11, 1990.

NATARO, J. P.; KAPER, J. B. Diarrheagenic Escherichia coli. Clinical Microbiology Review, v. 11, n. 1, p. 142-201, 1998.

OLIVER, J. D.; DAGHER, M.; LINDEN, K. Induction of Escherichia coli and Salmonella typhimurium into the viable but nonculturable state following chlorination of wastewater. Journal of Water Health, v. 3, n. 3, p. 249-57, 2005.

OMAR, B. The occurrence of pathogenic Escherichia coli in South African wastewater treatment plants as detected by multiplex PCR. Water SA, v. 36, n. 2, p. 172-176, 2010.

OZCAN, G. Numerical Model (Mike21) Applications in Outfall Design Case Studies. In: INTERNATIONAL CONFERENCE ON MARINE WASTE WATER DISCHARGES MWWD, 2., 2002. Istambul, Turkie. Proceedings... Washington: The World Bank, 2002.

POMMEPUY, M.; FIKSDAL, L.; GOURMELON, M.; MELIKECHI, H.; CAPRAIS, M. P.; CORMIER, M. et al. Effect of seawater on Escherichia coli beta-galactosidase activity. Journal of Applied Bacteriology, v. 81, n. 2, p. 174-180, 1996a.

POMMEPUY, M.; BUTIN, M.; DERRIEN, A.; GOURMELON, M.; COLWELL, R. R.; CORMIER, M. Retention of Enteropathogenicity by Viable but Nonculturable Escherichia coli Exposed to Seawater and Sunlight. Applied Environmental Microbiology, v. 62, n. 12, p. 4621-4626, 1996 b.

RHODES, K. Survival of Escherichia coli and Salmonella spp. in estuarine environments. Applied and Environmental Microbiology, v. 54, n. 12, p. 2902-2907, 1988.

RHODES, K. Effects of sunlight and autochthonous microbiota on Escherichia coli survival in an estuarine environment. Current Microbiology, v. 21, p. 65-73, 1990.

RIPPY, M. A.; FRANKS, P. J.; FEDDERSEN, F.; GUZA, R. T.; MOORE, D. F. Factors controlling variability in nearshore fecal pollution: the effects of mortality. Marine $\begin{array}{lllllll}\text { Pollution Bulletin, } & \text { v. 66, } & \text { n. } 1-2, & \text { p. 191-198, }\end{array}$ https://dx.doi.org/10.1016/j.marpolbul.2012.09.003

RODRIGUES, M.; OLIVEIRA, A.; GUERREIRO, M.; FORTUNATO, A. B.; MENAIA, J.; DAVID, L. M. et al. Modeling fecal contamination in the Aljezur coastal stream (Portugal). Ocean Dynamics, v. 61, n. 6, p. 841-856, 2011. https://dx.doi.org/10.1007/s10236-011-0392-9

ROZEN, B. Survival of enteric bacteria in seawater. FEMS Microbiology Reviews, v. 25, p. 513-529, 2001.

SHARMA, U. K.; CHATTERJI, D. Transcriptional switching in Escherichia coli during stress and starvation by modulation of sigma activity. FEMS Microbiology Reviews, v. 34, n. 5, p. 646-657, 2010.

SIEGELE, K. Life after log. Journal of Bacteriology, v. 174, n. 2, p. 345-348, 1992.

SINTON, L. W.; FINLAY, R. K.; LYNCH, P. A. Sunlight inactivation of fecal bacteriophages and bacteria in sewage-polluted seawater. Applied and Environmental Microbiology, v. 65 , n. 8, p. 3605-3613, 1999. 
SINTON, L. W.; HALL, C. H.; LYNCH, P. A.; DAVIES-COLLEY, R. J. Sunlight Inactivation of Fecal Indicator Bacteria and Bacteriophages from Waste Stabilization Pond Effluent in Fresh and Saline Waters. Applied and Environmental Microbiology, v. 68, n. 3, p. 1122-1131, 2002. https://dx.doi.org/10.1128/aem.68.3.1122-1131.2002

STEETS, B. M.; HOLDEN, P. A. A mechanistic model of runoff-associated fecal coliform fate and transport through a coastal lagoon. Water Research, v. 37, n. 3, p. 589-608, 2003.

TAIMUR-KHAN, M. M.; PYLE, B. H.; CAMPER, A. K. Specific and rapid enumeration of viable but nonculturable and viable-culturable gram-negative bacteria by using flow cytometry. Applied and Environmental Microbiology, v. 76, n. 15, p. 5088-96, 2010. https://dx.doi.org/10.1128/AEM.02932-09

TROUSSELLIER, M.; BONNEFONT, J-L.; COURTIES, C.; DERRIEN, A.; DUPRAY, E.; GAUTHIER, M. et al. Responses of enteric bacteria to environmental stresses in seawater. Oceanologica Acta, v. 21, n. 6, p. 965-981, 1998.

UNITED STATES. Environmental Protect Agency - USEPA. National Water Quality Inventory: Report to Congress - 2004 Reporting Cycle. Washington, 2009.

VAN ELSAS, J. D.; SEMENOV, A. V.; COSTA, R.; TREVORS, J. T. Survival of Escherichia coli in the environment: fundamental and public health aspects. The ISME Journal, v. 5, n. 2, p. 173-183, 2011. https://dx.doi.org/10.1038/ismej.2010.80

XU, H-S.; ROBERTS, N.; SINGLETON, F. L.; ATTWELL, R. W.; GRIMES, D. J.; COLWELL, R. R. Survival and Viability of Nonculturable Escherichia coli and Vibrio cholerae in the Estuarine and Marine Environment. Microbial Ecology, v. 8, n. 4, p. 313323, 1982. https://dx.doi.org/10.1007/BF02010671

YANG, L.; CHANG, W-S.; HUANG, W-Na L. Natural disinfection of wastewater in marine outfall fields. Water Research, v. 34, n. 3, p. 743-750, 2000.

ZHANG, Q.; HE, X.; YAN, T. Differential Decay of Wastewater Bacteria and Change of Microbial Communities in Beach Sand and Seawater Microcosms. Environmental Science and Technology, v. 49, n. 14, p. 8531-8540, 2015. https://dx.doi.org/10.1021/acs.est.5b01879

ZHU, X.; WANG, J. D.; SOLO-GABRIELE, H. M.; FLEMING, L. E. A water quality modeling study of non-point sources at recreational marine beaches. Water Research, v. 45, n. 9, p. 2985-2995, 2011. https://dx.doi.org/10.1016/j.watres.2011.03.015 